\title{
O ATIVISMO JUDICIAL NORTE-AMERICANO E BRASILEIRO: Características, Paralelo, Sustentabilidade e Influência das Decisões Ativistas Estadunidenses no Direito Pátrio ${ }^{1}$
}

http://dx.doi.org/10.21527/2176-6622.2019.51.100-110

Recebido em: 2/10/2018

Aceito em: 27/11/2018

\section{Magno Federici Gomes}

Estágio Pós-doutoral em Direito Público e Educação pela Universidade Nova de Lisboa-Portugal (Bolsa Capes/BEX 3642/07-0). Estágios Pós-doutorais em Direito Civil e Processual Civil. Doutorado em Direito e Mestrado em Direito Processual pela Universidad de Deusto-Espanha (Bolsa da Cátedra Unesco e do Gobierno Vasco-Espanha). Mestrado em Educação pela PUC Minas. Professor do Doutorado e Mestrado Acadêmico em Direito Ambiental e Desenvolvimento Sustentável na Escola Superior Dom Helder Câmara. Professor-adjunto da PUC Minas e professor titular licenciado da Faculdade de Direito Arnaldo Janssen. Líder do Grupo de Pesquisa: Regulação Ambiental da Atividade Econômica Sustentável (Rega)/CNPq-BRA e integrante dos grupos: Centro de Investigação \& Desenvolvimento sobre Direito e Sociedade (Cedis)/FCT-PT, Núcleo de Estudos sobre Gestão de Políticas Públicas (Negesp)/CNPq-BRA e Metamorfose Jurídica/CNPq-BRA. http://lattes.cnpq.br/1638327245727283. http://orcid.org/0000-0002-4711-5310. federici@pucminas.br

\section{Ana Luiza Novais Cabral}

Advogada. Doutoranda em Direito Público na área Democracia, Constituição e Internacionalização na Pontifícia Universidade Católica de Minas Gerais. Mestrado em Direito Ambiental pela Escola Superior Dom Helder Câmara. Pós-Graduação em Direito Tributário pela Faculdade Gama Filho. Pós-Graduação em Direito Ambiental pela Faculdade Integrada AVM. Graduação em Direito pela Faculdade de Ciências Sociais Aplicadas Newton Paiva. Pesquisadora do Grupo de Pesquisa "A possibilidade da defesa dos ambientes pelo Direito Penal". http://lattes.cnpq.br/2623437173992273. anamutum@hotmail.com

\section{RESUMO}

O ativismo judicial é tema controverso. Tal assertiva revela-se nos inúmeros casos emblemáticos atuais em que normas abertas dão azo a incongruências valorativas e decisões judiciais inovadoras que refletem os anseios sociais. Paradoxalmente, o ativismo judicial quebra o princípio constitucional da separação dos Poderes e, assim, o Poder Judiciário se legitima nas deliberações de políticas em contramão à inércia dos poderes políticos. Assim, utilizando uma metodologia teórico-jurídico com raciocínio dedutivo, por meio de análise doutrinária e jurisprudencial, serão observadas importantes decisões ativistas norte-americanas que influenciaram diretamente julgamentos brasileiros e como suas consequências favorecem a satisfação social e suas garantias básicas.

Palavras-chave: Ativismo judicial. Judicialização da política. Emblemáticas decisões ativistas. Influência do direito norte-americano. Sustentabilidade.

THE AMERICAN AND BRAZILIAN JUDICIAL ACTIVISM:

CHARACTERISTICS, PARALLEL, SUSTAINABLE AND INFLUENCE OF THE UNITED STATES DECISIONS IN THE BRAZILIAN LAW

\section{ABSTRACT}

Judicial activism is a controversial issue. Such an assertion is revealed in the numerous emblematic cases in which open standards give rise to value incongruities and innovative judicial decisions that reflect social longings. Paradoxically, judicial activism breaks the Constitutional principle of the separation of powers and, thus, the judiciary legitimizes itself in the deliberations of policies against the inertia of the political powers. Thus, using a theoretical-legal methodology with deductive reasoning and based on Brazilian doctrine and jurisprudence, it will analyze important American activist decisions that directly influenced Brazilian judgments and how their consequences favor social satisfaction and its basic guarantees.

Keywords: Judicial activism. Judicialization of the policy. Emblematic activist decisions. Influence of american law. Sustainable.

\section{SUMÁRIO}

1 Introdução. 2 Aspectos primordiais sobre o ativismo judicial. 2.1 Ativismo judicial nos Estados Unidos da América: histórico e suas repercussões. 2.2 O Ativismo judicial no direito brasileiro. 3 A commonolização do direito brasileiro. 4 . A influência das decisões ativistas norte-americanas no direito brasileiro e suas repercussões. 5. Considerações Finais. 6. Referências.

\footnotetext{
1 Trabalho financiado pelo Projeto Fapemig no 5236-15, resultante dos Grupos de Pesquisas (CNPq): Regulação Ambiental da Atividade Econômica Sustentável (Rega), Negesp, Metamorfose Jurídica e Cedis (FCT-PT).
} 


\section{INTRODUÇÃO}

O Poder Judiciário atualmente encontra-se numa posição estratégica em detrimento dos demais poderes políticos, tendo em vista a alta demanda e a judicialização das mais diversas questões cotidianas. Essa participação ativa e inovadora do Poder Judiciário em matérias decisórias políticas tem se tornado a solução de problemas sociais, ao mesmo tempo em que, doutrinariamente, existem enormes críticas principalmente quanto à usurpação dos outros Poderes.

Nos Estados Unidos da América (EUA), a proliferação do Ativismo Judicial se retrata, principalmente, como forma de autocontenção de um Poder Legislativo forte e atuante. Em contrapartida, no Brasil o ativismo judicial é descrição de uma inércia e falta de vontade política dos Poderes Legislativo e Executivo. Com isso, realizar a diferenciação de ambos e suas consequências torna-se matéria de suma importância.

Desta forma, a primeira disposição clara no presente artigo encontra-se na conceituação de ativismo judicial e, posteriormente, seu histórico e desmembramento nos direitos norte-americano e brasileiro.

Posteriormente, passa-se a analisar institutos que foram trazidos do direito norte-americano e incorporados ao direito brasileiro. O legislador, de forma inteligente, realiza um paralelo de fenômenos com resultados positivos em outros sistemas jurídicos. Não é novidade que o sistema Common Law e suas prerrogativas influenciam diretamente no direito pátrio e, assim, a adequação e utilização de institutos similares é uma forma de proporcionar a evolução do próprio.

Nesse contexto, é traçado um paralelo entre as decisões ativistas norte-americanas e brasileiras, colocando aspectos diversos sobre os atuais julgados. Empregou-se uma metodologia teórico-jurídico com raciocínio dedutivo, por meio de análise doutrinária.

\section{ASPECTOS PRIMORDIAIS SOBRE O ATIVISMO JUDICIAL}

Primeiramente, antes de se adentrar propriamente no termo e conceituação do ativismo judicial no direito estadunidense e sua influência nas decisões judiciais brasileiras, tema específico do presente artigo, faz-se necessário definir a judicialização da política, tendo em vista ser esse um gênero e ativismo judicial da sua espécie. A judicialização da política foi identificada primordialmente em 1803 no emblemático caso Marbury versus Madison, proferido pela Suprema Corte norte-americana, no qual foi configurada uma atuação ativa do Poder Judiciário no controle dos atos do Poder Legislativo (BINENBOJM, 2004, p. 121-137).

A judicialização da política tornou-se um fenômeno mundial e cada vez mais utilizado pela população, com o intuito de resguardar os direitos básicos e não desprendidos adequadamente pelos poderes políticos. Assim, judicializar matérias que seriam de alçada dos Poderes Legislativo e Executivo para cumprir os objetivos primordiais da Constituição, é uma segurança de que os preceitos primários poderão ser atendidos. A utilização desenfreada do instituto, no entanto, trouxe um desmedido abarrotamento do Poder Judiciário e, consigo, suas consequências.

No Brasil, o assunto retrodescrito rendeu diversas doutrinas e discrepantes entendimentos sobre o assunto. José Ribas Vieira, descrevendo sobre a judicialização da política, relata que ela "consiste em uma nova atribuição de papéis à prestação jurisdicional, com o escopo de resolver conflitos sociais em meio a uma sociedade repleta de novas formas de proteção jurídica" (VIEIRA, 2009, p. 45). Continuando sua definição, Vieira assevera que nesse "contexto, de uma presença mais efetiva do direito, cria-se, como consequência lógica, um processo de judicialização de demandas sociais, preocupadas com a concretização do amplo elenco de Direitos Fundamentais" (2009, p. 45).

Desta forma, com a possibilidade de judicialização de matérias de cunhos moral, social ou político, o Poder Judiciário torna-se o protagonista de um novo modelo se colocando num ponto bastante estratégico em detrimento dos outros Poderes, o que faz nascer, assim, o ativismo judicial, uma espécie de judicialização da política que inova proativamente no ordenamento jurídico. Nesse sentido,

Ainda que a judicialização da política tenha alçado dimensões globais nas democracias ocidentais pela constatação dos fatores políticos acima apontados, ela apenas se tornou prática recorrente em países cujo comportamento judicial pró-ativo tenha ocorrido de forma proporcional ao grau de discordância das Cortes Constitucionais em relação às decisões das instituições majoritárias (SOUZA; GOMES, 2015, p. 40). 
A possibilidade de ampliação da atuação do Poder Judiciário pela judicialização da política em detrimento de matérias que, a princípio, não seriam de sua competência, por ora trouxe opiniões favoráveis, ora desfavoráveis entre os juristas. Quanto aos malefícios, o fenômeno esbarra no excesso de interferência do Poder Judiciário em detrimento dos outros Poderes políticos, infringindo, assim, o princípio da separação dos Poderes. Um fator positivo é que tal fenômeno concede à sociedade uma resolução mais ágil e eficaz quanto às matérias que forem pleiteadas.

Mesmo, entretanto, que a judicialização traga uma possível resposta mais célere do que lhes trariam os Poderes políticos, com a alta demanda judicial, a morosidade começa a assombrar e constituir rejeições sociais. Atualmente tudo é judicializado. A vida tornou-se judicializável (BARROSO, 2009, p. 2-3) e, desta forma, a judicialização de matérias tipicamente políticas e a constante influência do Poder Judiciário, por vezes, faz nascer o instituto descrito como ativismo judicial, sendo este uma espécie da judicialização, o que a seguir é reproduzido.

\subsection{Ativismo Judicial nos Estados Unidos da América: histórico e suas repercussões}

O ativismo judicial teve sua origem no direito norte-americano, mas, aos poucos, tal fenômeno pode ser constatado nos mais diversos sistemas jurídicos do mundo. O termo ativismo judicial (judicial activism) foi usado primeiramente em um artigo da Revista Fortune, intitulado "The Supreme Court: 1947", no qual o autor, mesmo que de forma dúbia na classificação dos ativistas, descrevia os constantes desentendimentos ideológicos dentro da Suprema Corte norte-americana que dividia os votos dos ministros liberais e conservadores daquela casa (RAMOS; OLIVEIRA JUNIOR, 2014, p. 26-27).

O primeiro passo rumo ao ativismo judicial norte-americano aconteceu por meio do controle de constitucionalidade realizado pelo Poder Judiciário em detrimento das leis do parlamento no caso emblemático anteriormente descrito Marbury versus Madison, em 1803, quando a Suprema Corte norte-americana, por intermédio do controle de constitucionalidade, rechaçou a utilização interpretativa da legislação em vigor declarando a norma inconstitucional. Assim,

Marbury v. Madison foi a primeira decisão na qual a Suprema Corte afirmou o seu poder de exercer o controle de constitucionalidade, negando aplicação a leis que, de acordo com a sua interpretação, fossem inconstitucionais. Assinale-se, por relevante, que a Constituição não conferia a ela ou qualquer outro órgão judicial, de modo explícito, competência dessa natureza. Ao julgar o caso, a Corte procurou demonstrar que esta atribuição decorreria logicamente do sistema. A argumentação desenvolvida por Marshall acerca da supremacia da Constituição, da necessidade do judicial review e da competência do Judiciário na matéria é tida como primorosa (BARROSO, 2008, p. 275).

Os primeiros casos descritos de controle de constitucionalidade norte-americano tratavam acerca de aspectos econômicos e trabalhistas. Com o passar dos anos, os juízes saíram da esfera proeminentemente individual para adentrar em matérias de ações coletivas ou de classes.

Realizado esse brevíssimo escorço do ativismo judicial da Suprema Corte Norte-americana, verifica-se que o ativismo ali praticado, durante os períodos estudados, pode ser classificado em três fases: 1) a da contenção do poder legiferante dos Estados membros (ativismo de fortalecimento do Governo Federal); 2) a da contenção do poder de regulamentação da economia, de acordo com determinada política econômica (a do liberalismo político); e 3) a da contenção da atividade legislativa - estadual e federal - no que se refere a limitações de direitos e garantias individuais previstos na Constituição (Bill of Rights) (RAMOS; OLIVEIRA JUNIOR, 2014, p. 37).

A mudança nos modos de como comportava-se a Suprema Corte norte-americana começou a ter reflexos a partir do New Deal, de como o Poder Judiciário passou a intervir mais sensivelmente nas relações sociais. Observa-se o Poder Judiciário com uma postura ativista em que "suas decisões eram marcadas por um forte componente político - embora de caráter não-intervencionista - que, ao final, invadia o âmbito de produção legislativa" (TRINDADE; MORAIS, 2011, p. 139-140). 
O período denominado New Deal foi marcado por várias mudanças políticas, mas principalmente econômicas. Neste período, "fundamentando mudanças em termos constitucionais, como bem-estar, o comércio e o devido processo, amplia-se a competência do governo federal, que passa a ser admitida pela Suprema Corte" (BERNARDES, 2010, p. 213). A autora continua a descrever a época denominada New Deal como uma base para "fomentar a colaboração entre a União e Estados-Membros e fala-se em federalismo cooperativo, mas com grande predominância dos poderes federais, principalmente para tornar eficazes medidas de intervenção social" (p. 214).

O então presidente Franklin Roosevelt, assumindo seu posto em 1933, realizou uma série de intervenções financeiras que, posteriormente, mudariam o rumo da economia norte-americana. A Suprema Corte, no entanto, tentou barrar o plano financeiro progressista proposto por Roosevelt em razão do entendimento de ser contrário à Constituição. Com o aumento de vagas na Suprema Corte, todavia, ocorreu uma mudança de postura que passou a coadunar com o plano proposto pelo então chefe do Executivo Federal americano.

Nasce, assim, o ativismo judicial positivo, em que a Corte Suprema interfere em âmbitos que perpassam matérias jurídicas, mudando posicionamentos paradigmáticos, entendimentos orientadores inflexíveis e inovando criativamente no ordenamento jurídico, características típicas de atos ativistas. Desta forma, "inseridos na tradição da common law, os juízes deixaram de simplesmente interpretar as leis e passaram a reescrevê-las" (TRINDADE; MORAIS, 2011, p. 140).

O ápice do ativismo judicial naquele país ocorreu com o julgamento do caso Brown versus Board Education, em 1954, em que se discutiu a eliminação da segregação racial nas escolas públicas do sul dos EUA. Nele, permitiu-se que os negros ingressassem em escolas públicas que possuíam somente pessoas de cor branca, pondo fim à doutrina "iguais, mas separados" (equal, but separate), e revogando o precedente anterior utilizado no caso Plessy versus Ferguson, em que os negros teriam acomodações em transporte ferroviário iguais aos brancos, mas em alas separadas (RAMOS; OLIVEIRA JUNIOR, 2014, p. 36-37). Nesse sentido, tem-se:

A Suprema Corte norte-americana entendeu que era inconstitucional a admissão de estudantes em escolas públicas americanas com base num sistema de segregação racial. Ao determinar a aceitação da matrícula de estudantes negros numa escola pública até então dedicada à educação de pessoas brancas, a Suprema Corte deu início a um processo amplo de mudança do sistema público de educação naquele país, fazendo surgir o que se chamou de structural reform (DIDIER JÚNIOR; ZANETI; OLIVEIRA, 2017, p. 48).

A partir da década de 60, o ativismo judicial teve um exponencial crescimento no cenário jurídico norte-americano por meio de julgamentos de célebres casos com mudanças de precedentes. $O$ que era concreto no Poder Judiciário norte-americano, com seus precedentes definitivos, passou a seguir uma nova orientação com atos eminentemente ativistas, promovendo uma inovação decisória.

Muitos dos julgamentos considerados quebra de paradigmas modificando o cunho deliberativo do tribunal americano, acabaram influenciando as decisões das cortes brasileiras com julgados semelhantes, quando segue o mesmo padrão americano. A título de exemplo, destacam-se os prestigiados casos Gideon versus Wainwright, em 1963, dando aos acusados o direito à assistência judiciária gratuita, o que serviria para todos aqueles que comprovassem não possuir condições de constituir advogado, e o caso Miranda versus Arizona, em 1966, que dá garantias de não autoincriminação, sendo posteriormente descrito no artigo 5o, inciso LXIII, da Constituição Federal de 1988 (CF/88), relatando que "o preso será informado de seus direitos, entre os quais o de permanecer calado, sendo-lhe assegurada a assistência da família e de advogado" (BRASIL, 1988).

Com o que fora exposto, percebe-se uma grande influência nos inovadores precedentes ativistas com os julgamentos posteriormente realizados no Brasil. Embora os modelos se associem, a criação do ativismo judicial e o seu emprego possuem aspectos diferentes. $O$ ativismo judicial norte-americano é uma forma de barrar os excessos provocados pelo Poder Legislativo e, em contrapartida, no Brasil, o ativismo judicial é um meio de minimizar a letargia dos outros Poderes, garantindo assistência à população que dela necessitar. Segundo Ramos e Oliveira Junior (2014):

Enquanto o ativismo norte-americano parece ter por objeto a contenção da atividade legislativa, o ativismo brasileiro não visa à contenção de excessos cometidos por outros Poderes, mas sim à compensação da inação do Poder Legislativo e Executivo, na implementação de determinados direitos previstos na Constituição ou em resposta a certos reclamos do corpo social (p. 37). 
Ainda que o ativismo judicial tenha imperado por algum tempo na Suprema Corte americana, durante os períodos de 1986 a 2005 o então presidente da Corte (Chief Justice), William Rehnquist, passa a uma postura conservadora de autocontenção judicial. Algumas decisões foram revisadas, no entanto a intenção primeira de conservadorismo fora apenas parcial, posto que vários precedentes ativistas continuaram a imperar naquela época.

Com a morte de William Rehnquist, o então presidente da república George W. Bush indica para a vaga de presidente da Corte John Glover Roberts Jr., o qual é devidamente aprovado pelo Senado. O Chief Justice assume primordialmente com uma postura de fazer com que as decisões na Corte Suprema se tornem mais uniformes e com menos discrepâncias, o que não se consumou, tendo em vista as posições conservadoras e modernas (liberais) que se encontravam naquele tribunal.

Percebe-se que os atos ativistas proferidos pela Corte Suprema norte-america, bem como pelo Supremo Tribunal Federal (STF) do Brasil, estão diretamente ligados à composição dos mesmos. Quando o tribunal é mais conservador, a tendência é a autocontenção judicial, mas quando ele é mais progressista, o ativismo judicial é presenciado com mais frequência. A composição das Cortes influencia, portanto, de forma clara, no modo de julgar e nos precedentes judiciais que terão maior ímpeto.

A forte inclinação de utilizar parâmetros similares das decisões norte-americanas no direito brasileiro advém de aspectos culturais, morais e sociais, fazendo com que a ingerência de institutos americanos seja constantemente empregados no Brasil.

\subsection{O Ativismo Judicial no Direito Brasileiro}

Atualmente, o Poder Judiciário, principalmente por intermédio do STF, vem desempenhando uma atribuição proativa perante a sociedade. De certa forma, o novo papel desempenhado sofre críticas e debates entre os juristas. A Corte Máxima, quando provocada em dar respostas à população, não pode se eximir de julgar e encontrar uma solução plausível para aquela situação concreta naquele momento histórico. Desta forma, as questões com repercussões nacionais passam a ser solucionadas pelo Poder Judiciário e não por instâncias políticas (Legislativo e Executivo).

O ativismo judicial é uma espécie de judicialização da política, sendo descrito como "uma atitude, ou seja, a escolha de um modo específico e proativo de interpretar a Constituição, expandindo o seu sentido e alcance" (ABREU, 2013, p. 140). Continuando, o autor relata: "enfim, podemos concluir que o ativismo judicial se mostra como a ampliação do poder dos tribunais no controle dos demais poderes, pelo viés constitucional" (p. 142).

O fenômeno do ativismo judicial é tema atual e de constantes discussões jurídico-filosóficas, que tendem a se instalar quando o Poder Legislativo, órgão típico na atribuição da promulgação das leis, se mostra inerte ou omisso perante a sociedade, quando a mesma clama por mudanças ou inovações normativas. Quando o Poder Legislativo ignora algumas questões que a sociedade civil necessita alterar, o Poder Judiciário é provocado a decidir, e, não podendo se eximir, acaba inovando na ordem jurídica e legislativa sobre tal assunto.

O que ocorreu e o que vem ocorrendo em terrae brasilis: as decisões dos Tribunais são proferidas de acordo com a visão de cada componente, soçobrando, com isso, a legislação e, o que é pior, a Constituição. Sob pretexto de o juiz não ser mais o "juiz boca da lei” (positivismo primitivo), agora temos o juiz (tribunal), para quem (para qual) a lei é apenas - como diriam alguns doutrinadores adeptos de teorias voluntaristas - a ponta o iceberg. E, por vezes, nem mesmo isso...! No fundo, volta-se ao velho positivismo fático, versão voluntarista do realismo jurídico: a lei é aquilo que os Tribunais dizem que é (como que a repetir a famosa frase do juiz Oliver Holmes) (STRECK, 2013, p. 314).

O ativismo judicial é caracterizado em dois aspectos: quando invade a esfera do Poder Legislativo e proativamente inova no ordenamento jurídico, retirando do cidadão o seu direito democrático de ser representado por aquele que elegeu, e quando o juiz, vislumbrando uma lacuna legislativa, se utiliza desse aspecto para suprir a omissão de forma aparente a criar um novo precedente. 
Percebe-se que o juiz poderia ter decidido utilizando o direito posto, e a isso se inclui as normas, jurisprudência, súmulas e demais outros tantos aparatos que lhe valem. Inova no ordenamento jurídico, no entanto, o que em palavras simples se traduz na conclusão de que o magistrado se portou como legislador positivo, matéria típica do Poder Legislativo, órgão político e representado democraticamente por cidadãos eleitos.

Nesse sentido, o ativismo judicial ultrapassaria os limites impostos pela $\mathrm{CF} / 88$, adentrando na esfera do Poder Legislativo, perfazendo um conflito jurisdicional. Assim, "os juízes não são eleitos, bem como não são responsáveis perante os eleitores, como ocorre com os legisladores, logo não poderiam criar leis" (ABREU, 2013, p. 229).

Sobre o crescimento atual do ativismo judicial, percebe-se que uma das primeiras e principais causas é a inércia e/ou ineficácia do Poder Legislativo no cumprimento de suas atribuições típicas. $O$ ativismo judicial tem como causa a prática ou abstenção do poder político legiferante em sua atuação. Diante dessa premissa, o cidadão, necessitando ter acesso a normas mais contemporâneas, busca, por meio do Poder Judiciário, as soluções de suas controvérsias.

Inúmeros são os exemplos de ativismo judicial no cenário atual do país. Dentre eles pode-se citar o reconhecimento da união estável entre os homossexuais (ADI no 4.277/DF e ADPF no 132/RJ, rel. min. Ayres Britto, julgamento em 5/5/2011), o aborto nos casos de fetos anencefálicos (ADPF no 54, rel. min. Marco Aurélio, julgamento em 11/4/2012), a constitucionalidade para as pesquisas em células-tronco embrionárias (ADI no 3.510, rel. min. Ayres Britto, julgamento em 29/5/2008), e várias outras decisões emblemáticas em que o Poder Judiciário saiu de sua esfera de julgador e, mesmo podendo se utilizar da norma posta, discricionariamente decidiu inovar no ordenamento pátrio, criando, assim, uma solução que não estava descrita legislativamente.

Assim, na democracia, uma lei somente pode deixar de ser aplicada em seis hipóteses [...]: (a) quando a lei for inconstitucional, aplicando-se os mesmos mecanismos de controle de constitucionalidade; (b) na hipótese em que, na relação texto e norma, for cabível uma interpretação conforme a Constituição; (c) quando for caso de nulidade parcial sem redução de texto; (d) quando se tratar de resolução pelo critério das antinomias - com os devidos cuidados, é claro; (e) quando for caso de inconstitucionalidade parcial com redução de texto e (f) quando for uma hipótese de uma regra se chocar com um princípio constitucional, claro que com os cuidados relacionados ao pamprincipiologismo. Fora dessas hipóteses, se o julgador quiser elaborar uma nova lei - $e$ digo isso com toda a Ihaneza e respeito - deve se candidatar a uma vaga no Parlamento. Simples, pois (STRECK, 2015, p. 162, grifo próprio).

O que fazer, no entanto? Proibir o magistrado de interpretar? Parece essa a solução mais plausível para a erradicação do ativismo judicial? Fatores positivos e negativos nesse aspecto teórico sempre irão surgir. Colocar um freio no Poder Judiciário engessaria algumas questões suplicadas pela população.

\section{A COMMONOLIZAÇÃO DO DIREITO BRASILEIRO}

O Brasil, vislumbrando algumas características do direito norte-americano e que podem ser transportadas ao direito pátrio, se rende e traz para si institutos que possam auxiliar e melhorar o bom andamento processual e sua possível celeridade, sempre em busca da mais sonhada justiça ao caso concreto. Desse modo, "a facilidade de comunicação facilitou o diálogo entre famílias jurídicas distintas e, por decorrência, intensificou aquilo que denominamos commonlawlização do direito nacional, pois consequência das experiências colhidas junto a common law" (PORTO, 2006, p. 21).

Conforme o exposto, o juiz precisa adequar a legislação à contemporaneidade para dar ao caso concreto maiores possibilidades. $O$ que se percebe é uma enormidade de legislações razoáveis existentes, mas que são meramente simbólicas e não efetivas em razão do desuso e do fator temporal. É nessa fase que aparecem perspectivas que vão além daquilo que realmente a norma estabelece, ocorrendo o ativismo judicial.

Em resumo: não há como ignorar, tanto no common law como no civil law, que uma mesma norma jurídica pode gerar diversas interpretações e, por consequência, variadas decisões judiciais. Porém, o common law, certamente com a colaboração de um ambiente político e cultural propício, rapidamente intuiu que o juiz não poderia ser visto como mero revelador do direito costumeiro, chegando a atribuir-lhe a função de criador do direito, enquanto o civil law permanece presa à ideia de que o juiz simplesmente atua a vontade do direito. De 
modo que o common law pôde facilmente enxergar que a certeza jurídica apenas poderia ser obtida mediante o stare decisis, ao passo que o civil law, por ainda estar encobrindo a realidade, nos livros fala e ouve sobre a certeza jurídica na aplicação da lei, mas, em outra dimensão, sente-se atordoada diante da desconfiança da população, além de envolta num emaranhado de regras que, de forma não sistemática, tentam dar alguma segurança e previsibilidade ao jurisdicionado (MARINONI, 2008, p. 35).

De toda sorte, o magistrado deve adaptar à época atual o que for ultrapassado. É certo que o legislador está sempre atrasado aos anseios da sociedade, pois quando a lei é promulgada, ela em si já está aquém no tempo em razão do ciclo de seu trâmite, discussões e votações. Assim, a legislação, quando entra em vigor, em regra, já se encontra antiga numa sociedade que avança rapidamente em aspectos morais, sociais e tecnológicos àquela época em que a norma se encontrava em discussão. $O$ sistema, como um todo, encontra-se engessado evolutivamente.

A mudança no paradigma do sistema civil law do Brasil vem sendo feita, cada vez mais, por intermédio da utilização de outros parâmetros (fontes) com interferência da família common law. É o caso da jurisprudência, que está assumindo crescente importância no país. Nessa perspectiva, "há nítida aproximação entre os sistemas no que tange aos usos e experiências que têm se aplicado num e noutro, por meio de técnicas e metodologias originalmente estranhas às suas formações" (MENDES, 2013, p. 179).

Toda decisão precisa ter um resultado útil devidamente compatível com a situação concreta, mas as discrepâncias aparentes nos entendimentos e orientações trazem à tona discussões sobre a segurança jurídica e uma uniformização da jurisprudência para não tornar o Poder Judiciário uma loteria de sentenças divergentes. Fica claro, portanto, que não há uma coesão consistente nas decisões do Poder Judiciário.

A vulnerabilidade das decisões jurídicas, vivenciada por vários anos e altamente criticada pelos juristas, faz com que determinados mecanismos existentes em outros países ou sistemas sejam transportados para o ordenamento brasileiro e incorporados à realidade do país. É o caso da utilização cada vez mais constante de precedentes vinculantes pelos magistrados na orientação e fundamentação de suas decisões.

Ocorre, assim, a paulatina confluência entre os dois sistemas descritos: common law e civil law. $\mathrm{O}$ doutrinador Luiz Guilherme Marinoni, sobre o assunto ora explanado, delibera que: "A tarefa do juiz do civil law, na atualidade, está muito próxima da exercida pelo juiz do common law. Ora, é exatamente a cegueira para a aproximação das jurisdições destes sistemas que não permite enxergar a relevância de um sistema de precedentes no civil law" (2008, p. 41).

Como as legislações não caminham rapidamente de acordo com os anseios e solicitações da população, a jurisprudência se exalta. Sua aplicação ainda é vista como um percurso mais célere e otimizado nas decisões judiciais, em que os magistrados empregam uma ementa para justificar a sentença. Alguns doutrinadores criticam esse desenfreado método, no entanto, com a alta demanda, passa a ser usual e cotidiano esse fenômeno trazido do sistema common law, chamado por certos autores de "commonlawlização" do Direito brasileiro:

Realmente, a chamada "commonlawlização" do direito nacional é o que se pode perceber, com facilidade, a partir da constatação da importância que a jurisprudência, ou seja, as decisões jurisdicionais vêm adquirindo no sistema pátrio, particularmente através do crescente prestigiamento da corrente de pensamento que destaca a função criadora do juiz (PORTO, 2006, p. 6).

Com mais fácil acesso da população ao Poder Judiciário por meio de mecanismos mais céleres trazidos de outros sistemas jurídicos e a constante judicialização de matérias individuais e coletivas, várias matérias repetitivas portam-se como um entrave direto para o bom andamento da justiça. É por meio do intenso número de decisões semelhantes que os Tribunais superiores passam a decidir igualmente nas reiteradas ações.

Desta feita, uma decisão paradigmática proferida por um Tribunal superior passa a ser um parâmetro decisivo nas ações posteriores, fato ocorrido nas famílias anglo-saxônicas; caso bem semelhante aos precedentes utilizados no sistema common law, denominado de distinguishing, sendo este "método de confronto pelo qual o juiz verifica se o caso em julgamento pode ou não ser considerado análogo ao paradigma, podendo afastá-lo se as circunstâncias dos casos não coincidirem" (BERTAGNOLLI; BAGGIO, 2017, p. 179). 
O Direito brasileiro sofreu e vem cada vez mais recebendo uma grande influência do common law, principalmente no que diz respeito aos EUA, que não possuem sistema puro, mas se encontram na família anglo-saxônica mista, ressaltando os precedentes judiciais, mas com algumas legislações esparsas que corroboram o bom andamento processual e as descrições principiológicas do país.

Alguns fenômenos de inspiração estadunidense foram transportados ao Direito brasileiro, como o controle de constitucionalidade difuso e, é claro, a valorização dos precedentes judiciais, caso típico não somente daquele país, mas de todos que abarcam o sistema common law. É o que Luiz Roberto Barroso aponta como americanização do Direito brasileiro.

No curso do processo de incorporação desse modelo de constitucionalismo, os países da tradição romano-germânica passaram por transformações extensas e profundas. Dentre elas é possível destacar o fenômeno referido como constitucionalização do Direito, no qual se inserem a aplicação direta e imediata da Constituição às relações jurídicas em geral, o controle de constitucionalidade e a leitura do direito infraconstitucional à luz dos princípios e regras constitucionais. No mesmo contexto, juízes, tribunais e, especialmente, os tribunais constitucionais tornaram-se mais atuantes e ativistas, potencializando o desenvolvimento de novas categorias da interpretação constitucional (2008, p. 301).

Alguns julgados ativistas, considerados emblemáticos no Direito americano, arraigaram por outros sistemas jurídicos e influenciaram decisões ao redor do mundo. No Brasil, tal aspecto não poderia ter sido diferente. Desta forma, faz-se o estudo de algumas decisões peculiares norte-americanas que tiveram presença constante de argumentos usados no direito brasileiro.

\section{A INFLUÊNCIA DAS DECISÕES ATIVISTAS NORTE-AMERICANAS NO DIREITO BRASILEIRO E SUAS REPERCUSSÕES}

Realizando um paralelo das decisões ativistas no Direito norte-americano e no Direito brasileiro, percebe-se uma nítida diferença na utilização do fenômeno descrito. Enquanto no direito estadunidense, o ativismo judicial serve como uma autocontenção de um legislativo forte e atuante, no direito pátrio o instituto é usado primordialmente tendo em vista uma inércia ou atuação ineficiente dos poderes políticos e a falta de vontade de enfrentar determinados assuntos em que a sociedade clama por decisões mais aptas à atual conjuntura vivenciada pelo país. Assim, a norma se torna um reflexo da sociedade.

Dessa forma, o ativismo judicial é um fenômeno encontrado nos mais diversos sistemas jurídicos do mundo, incluindo o sistema misto norte-americano e o sistema Civil Law brasileiro. Várias decisões inovadoras ativistas estadunidenses acabaram por influenciar e ter grande relevância nas deliberações do direito brasileiro e, com isso, as transformações drasticamente modificaram parâmetros que antes eram considerados socialmente sólidos.

A Constituição americana detém a observância de ser sintética e com durabilidade arraigada, tendo em vista ter sido promulgada em 1787. Ao longo dos anos, a interpretação constitucional passou por diversas fases e reformas para que as normas andem de acordo com as evoluções da sociedade. Como, no entanto, um dos aspectos primordiais do direito norte-americano encaixa-se em precedentes, o ativismo judicial e suas consequências pioneiras acabaram por dar vazão e influenciar diversos sistemas jurídicos, dentre eles a família brasileira.

Conforme anteriormente descrito, o ativismo judicial obteve seu auge com o julgamento do caso Brown versus Board Education, em 1954, e a discussão sobre a eliminação da segregação racial nas escolas públicas do sul dos EUA, pondo fim à doutrina equal, but separate e revogando o precedente anterior utilizado no caso Plessy versus Ferguson, em que os negros teriam acomodações em transporte ferroviário iguais aos brancos, mas em alas separadas. Tal caso foi considerado o pioneiro, quebrando paradigmas e discutindo valores fundamentais anteriormente entendidos como sólidos naquela sociedade. 
Percebe-se que o caso é enfático em razão do histórico de segregação cultural nos EUA. No Brasil, a segregação racial não foi vislumbrada com tamanha força, mas os conceitos utilizados no julgamento citado foram transportados e até hoje são utilizados para enfatizar direitos fundamentais independentes de características físicas específicas" ${ }^{2}$ ampliando o conceito de que "todos são iguais perante a lei, sem distinção de qualquer natureza" (BRASIL, 1988).

Outros casos emblemáticos ativistas norte-americanos repercutiram não somente naquele país, mas ao redor do mundo. Um julgamento a ser analisado é o caso Roe v. Wade, em 1973, no qual a Suprema Corte garantiu o direito à interrupção da gravidez voluntariamente nos EUA, sob argumento do amparo à privacidade, descrito como um direito fundamental. Tal julgado ficou conhecido como um dos mais controvertidos e politicamente significativos norte-americano, tendo em vista a discussão não somente sobre o aborto, mas a percepção da data considerada começo da vida, a viabilidade da interrupção da gravidez voluntariamente, a saúde da mulher e sua liberdade pessoal.

Julgamento similar ocorrido no Brasil e iminentemente ativista, foi realizado a tratar sobre o aborto nos casos de fetos anencefálicos (ADPF no 54, rel. min. Marco Aurélio, julgamento em 11/4/2012). Em tal julgado, o STF concedeu a possibilidade de abortamento na situação descrita, dando, assim, uma nova prerrogativa a realizar o procedimento de interrupção da gravidez que não estava descrita no Código Penal Brasileiro (CPB). Os argumentos usados em plenário possuem similitude crassa aos parâmetros do julgamento sobre o aborto nos EUA, tendo sidos discutidos o instante em que a vida inicia, a saúde da gestante e o momento da realização do aborto.

Assim como no caso emblemático americano em que alguns seguimentos sociais foram ouvidos, no Brasil o mesmo aconteceu com a forte ocorrência do amicus curiae e novas visões sobre aspectos não somente jurídicos. Percebe-se a importância da abertura ao direito interdisciplinar e discussões de cunhos social, político, moral e religioso para chegar ao julgamento que mais bem atendesse ao reflexo atual do país. Assim, o STF concedeu uma nova possibilidade de aborto não descrito pelo CPB e que não passou por um processo legislativo apto, configurando, então, o ativismo judicial.

Prosseguindo, caso importante no direito norte-americano foi o julgamento Obergefell vs. Hodges, em 1971, no qual se reclamava a possibilidade do reconhecimento da união homossexual. O pedido retrodescrito abriu precedente para posteriores argumentações sobre a união entre pessoas do mesmo sexo, com amplo debate entre os juristas e nos mais diversos seguimentos sociais. Em que pese várias decisões no mesmo sentido tenham sido decididas naquele país, foi somente em 2015 que a Corte Suprema declarou inconstitucionais as leis que proíbem o matrimônio entre pessoas do mesmo sexo.

Decisão importante, e seguindo os mesmos argumentos proferidos pela Suprema Corte norte-americana, no Brasil o reconhecimento da união homoafetiva se deu por meio da ADI no 4.277/DF e ADPF no 132/RJ, sendo relator o ministro Ayres Britto, com julgamento datado de 5/5/2011. À época havia o projeto de Lei $n^{\circ}$ 1.151 tramitando sobre tal assunto, no entanto o Legislativo não tinha interesse político de discutir sobre o caso e, temendo represália social, imiscuir o fato tornou-se a saída mais hábil.

O STF, numa atitude ativista, reconheceu a possibilidade da união entre pessoas do mesmo sexo, e, em 2013, o Conselho Nacional de Justiça (CNJ) aprovou uma resolução que obriga todos os cartórios do país a celebrar casamentos entre homossexuais. Em julgamento, os argumentos intensificaram-se sobre a dignidade da pessoa humana e garantias fundamentais independente da opção sexual. Essa inovadora decisão coaduana com o reflexo social atualmente vivenciado. Como, todavia, a norma não anda juntamente com os anseios da população, o Poder Judiciário, principalmente por meio do STF, vem proferindo decisões que alcancem os pleitos sociais.

Foram transcritas algumas representativas decisões ativistas que marcaram historicamente as mudanças jurídicas, sociais e políticas do país. Ficou claro o entendimento de que vários argumentos usados em decisões norte-americanas foram transportados ao direito pátrio, influenciando os julgamentos. Assim, a influência, principalmente do direito norte-americano, diretamente nas decisões judiciais ativistas brasileiras, é aparen-

\footnotetext{
Para aprofundamento na dimensão jurídico política do desenvolvimento sustentável como forma de se assegurar os direitos fundamentais intergeracionais, ver GOMES; FERREIRA, 2017, p. 93-111.
} 
te. Tal ocorrência percebe-se tendo em vista a atuação do Poder Judiciário brasileiro em enfrentar situações das quais os Poderes políticos se esquivam. Como o fato acaba por ser judicializado, o Poder Judiciário, corajosamente, encara o caso de acordo com a época atual. Nesse sentido, a jurisdição sustentável destaca que:

Na construção da decisão ideal para o caso concreto, o desafio hermenêutico da jurisdição não é mais um singelo exercício de subsunção do fato à norma, mas sim uma intensa atividade de construção e ponderação, participativa e dialética, que considera os imprescindíveis aportes transdiciplinares e que projeta cautelosamente os efeitos e as consequências da decisão para o futuro (BODNAR, 2009, p. 106).

O ativismo judicial no Brasil é um fato, e, mesmo que haja muitas críticas, ele é necessário, essencial e irreversível para que o direito caminhe junto com as súplicas da sociedade. Esse mecanismo, trazido do sistema common law, torna mais eficiente o acesso à justiça, tendo em vista que, como há um déficit na representatividade política que deveria agir em nome da população, essa abertura do Poder Judiciário garante uma inovação normativa em prol de prerrogativas sociais.

\section{CONSIDERAÇÕES FINAIS}

De tudo o que foi exposto, resta novamente enfatizar a emergente atuação do Poder Judiciário por meio do ativismo judicial. Com a falta de atuação regente dos Poderes Executivo e Legislativo, no entanto, o fenômeno acaba por ser a ultima ratio da população em conseguir dispor de seus direitos.

Nesse contexto, o Poder Judiciário é colocado numa situação hierárquica estratégica, haja vista que é disposto a ele decidir diversos conflitos que seriam da alçada dos Poderes Legislativo e Executivo. A tendência de transferência das atribuições políticas ao Poder Judiciário forma o ativismo judicial, movimento com origem norte-americana que foi trazido ao país, assim como vários outros mecanismos que facilitam o acesso à justiça.

Desta forma, mediante uma atuação proativa do Poder Judiciário, a sociedade consegue transitar juntamente com as evoluções que a comunidade passa. Com a intensa globalização e articulações entre os países, é preciso redefinir alguns conceitos para ajustar ao novo cenário brasileiro. Percebe-se que os sistemas jurídicos ao redor do mundo não estão isolados; ao contrário, quando certo instrumento tende a dar um bom trâmite processual, obter maior celeridade, minorar custos e dar amplo acesso à jurisdição, ele é estendido e transportado a outras famílias jurídicas. Assim, vários mecanismos são trazidos ao país, principalmente os do direito norte-americano.

Apesar dos inúmeros questionamentos pela ausência de diálogo institucional, o ativismo judicial no Brasil é indispensável aos anseios sociais de efetivação dos direitos fundamentais, pela implementação da dimensão jurídico política da sustentabilidade e de uma jurisdição sustentável. Ele foi importado do direito norte-americano e possui influência direta nas decisões brasileiras e, com isso, as inovações surgem e alcançam o parâmetro social adequado.

\section{REFERÊNCIAS}

ABREU, João Paulo Pirôpo de. A autonomia financeira do Poder Judiciário: limites traçados pelo princípio da independência e harmonia dos poderes. Brasília: Centro de Estudos Judiciários, 2013.

BARROSO, Luis Roberto. Judicialização, ativismo judicial e legitimidade democrática. Revista de Direito do Estado, Rio de Janeiro, n. 13, jan./mar. 2009. Disponível em: http://www.oab.org.br/editora/revista/users/revista/1235066670174218181901.pdf. Acesso em: 8 jan. 2018.

BARROSO, Luis Roberto. A americanização do direito constitucional e seus paradoxos: teoria e jurisprudência constitucional no mundo contemporâneo. Caderno da Escola de Direito e Relações Internacionais, v. 2, n. 9, p. 258-301, 2008. Disponível em: http://revistas.unibrasil.com.br/cadernosdireito/index.php/direito/article/view/459. Acesso em: 8 jan. 2018.

BERTAGNOLLI, Ilana; BAGGIO, Andreza Cristina. Os precedentes vinculantes do novo Código de Processo Civil e a aproximação entre Common Law e Civil Law no direito brasileiro. Revista lus Gentium, Curitiba, v. 8, n. 1, p. 162-181, jan./jun. 2017. Disponível em: https://www.uninter.com/iusgentium/index.php/iusgentium/article/view/325. Acesso em: 10 jan. 2018.

BERNARDES, Wilba Lúcia Maia. Federação e federalismo. Belo Horizonte: Editora Del Rey, 2010.

BINENBOJM, Gustavo. A nova jurisdição constitucional brasileira: legitimidade democrática e instrumentos de realização. Rio de Janeiro: Renovar, 2004. 
BODNAR, Zenildo. Os novos desafios da jurisdição para a sustentabilidade na atual sociedade de risco. Revista Veredas do Direito, Belo Horizonte, v. 6, n. 12, p. 101-119, jul./dez. 2009. Disponível em: http://www.domhelder.edu.br/revista/index.php/ veredas/article/view/19. Acesso em: 2 out. 2018.

BRASIL. Constituição da República Federativa do Brasil de 1988. Diário Oficial da União, Brasília, 5 out. 1988. Disponível em: http://www.planalto.gov.br/ccivil_03/constituicao/ConstituicaoCompilado.htm. Acesso em: 8 jan. 2018.

DIDIER JÚNIOR, Fredie; ZANETI JÚNIOR, Hermes; OLIVEIRA, Rafael Alexandria de. Notas sobre as decisões estruturantes. Civil Procedure Review, v. 8, n. 1, p. 46-64, jan./abr. 2017. Disponível em: http://www.civilprocedurereview.com/?option=com_content\&view=article\&id=361:pdf-revista-n1-2017. Acesso em: 2 ago. 2019.

GOMES, Magno Federici; FERREIRA, Leandro José. A dimensão jurídico-política da sustentabilidade e o direito fundamental à razoável duração do procedimento. Revista do Direito, Santa Cruz do Sul, n. 52, v. 2, p. 93-111, maio/set. 2017. Disponível em: https://online.unisc.br/seer/index.php/direito/article/view/8864. Acesso em: 2 out. 2018.

MARINONI, Luiz Guilherme. Aproximação crítica entre as jurisdições de civil law e de common law e a necessidade de respeito aos precedentes no Brasil. Revista da Faculdade de Direito - UFPR, Curitiba, n. 47, p. 29-64, 2008. Disponível em: http://www. revistas.ufpr.br/direito/article/viewFile/17031/11238. Acesso em: 10 jan. 2018.

MENDES, Bruno Cavalcanti Angelin. A jurisdição e a aproximação entre os sistemas jurídicos do common law e do civil law. Revista Periódica da Faculdade de Belém, v. 2, n. 1, p. 151-187, jan./jun. 2013. Disponível em: http://www.fabelnet.com.br/ portal/images/revista-ensinagem/3-edicao/A_JURISDICAO_E_A_APROXIMACAO.pdf. Acesso em: 10 jan. 2018.

PORTO, Sérgio Gilberto. Sobre a common law, civil law e o precedente judicial. In: MARINONI, Luiz Guilherme (org.). Estudos de direito processual civil - homenagem ao professor Egas Dirceu Moniz de Aragão. São Paulo: RT, 2006. p. 1-26. Disponível em: http://www.abdpc.org.br/abdpc/artigos/sergio\%20porto-formatado.pdf. Acesso em: 10 jan. 2018.

RAMOS, Paulo Roberto Barbosa; OLIVEIRA JUNIOR, Jorge Ferraz de. Características do ativismo judicial nos Estados Unidos e no Brasil. Um breve histórico do ativismo judicial na Suprema Corte Norte-Americana e um paralelo com o recente ativismo judicial da Suprema Corte Brasileira. Revista de Informação Legis/ativa, v. 51, n. 204, p. 25-42, out./dez. 2014. Disponível em: http://www2.senado.leg.br/bdsf/item/id/509926. Acesso em: 8 jan. 2018.

SOUZA, Isabella Saldanha de; GOMES, Magno Federici. Ativismo judicial, democracia e sustentabilidade. Rio de Janeiro: Lúmen Juris, 2015.

STRECK, Lenio Luiz. Compreender Direito: nas brechas da lei. São Paulo: Revista dos Tribunais, 2015. V. 3.

STRECK, Lenio Luiz. Jurisdição constitucional e decisão jurídica. 3. ed. São Paulo: Revista dos Tribunais, 2013.

TRINDADE, André Karam; MORAIS, Fausto Santos de. Ativismo judicial: as experiências norte-americana, alemã e brasileira. Revista da Faculdade de Direito - UFPR, Curitiba, n. 53, p. 137-164, 2011. Disponível em: http://revistas.ufpr.br/direito/article/ view/30764. Acesso em: 8 jan. 2018.

VIEIRA, José Ribas. Verso e reverso: a judicialização da política e o ativismo judicial no Brasil. Estação Científica (Ed. Especial Direito), Juiz de Fora, v. 1, n. 4, p. 44-57, out./nov. 2009. Disponível em: http://docplayer.com.br/16656597-Verso-e-reverso-a-judicializacao-da-politica-e-o-ativismo-judicial-no-brasil.html. Acesso em: 8 jan. 2018. 